\title{
Samoocena dziecka - źródła i komunikaty weryfikujące
}

\section{Self-concept of the child versus verification messages and their sources}

\section{Streszczenie:}

W artykule zwrócono uwagę na źródła i mechanizmy kształtowania się samooceny dziecka. Usłyszane komunikaty oceniające od osób znaczących, zarówno ich treść jak i forma, przyczyniają się do kreacji wewnętrznego obrazu siebie i świata. Badanie samooceny na poziomie jawnym, świadomym jest obarczone istotnym błędem, dlatego warto poszukiwać sposobów weryfikacji poziomu samozadowolenia w sposób ukryty, poprzez pytania „nie wprost".

Słowa kluczowe: samoocena dziecka, poczucie wartości, styl wyjaśniania

\begin{abstract}
:
The article points out the sources and mechanisms of the child's self-concept formation. Evaluation messages heard from important people, both their content and form, contribute to the creation of an internal image of oneself and the world. Examining self-concept on a conscious level, is subject to significant error; therefore, it is worth looking for ways of verifying the level of complacency in a hidden manner, through "indirect" questions.
\end{abstract}

Keywords: child's self-concept, self-esteem, style of explanation 
Aleksandra Jędrzejewska - Samoocena dziecka...

Osobowość człowieka formuje się do około 18 roku życia, powoli kształtując obraz świadomego Ja, składający się z dwóch aspektów: samowiedzy - elementu poznawczego oraz samooceny - komponentu emocjonalnego, wzajemnie na siebie wpływających ${ }^{1}$. Początki poznawania siebie, w znacznym stopniu pochodzą od informacji z otoczenia, które tworzą tzw. ja odzwierciedlone². Kolebką tej struktury jest rodzina, wraz jej członkami-wzorcami i relacjami między nimi. Z czasem, w życiu dziecka pojawia się coraz więcej osób znaczących, które wpływają na kształtowanie poczucia siebie. Są to nie tylko osoby dorosłe, ale również koledzy i koleżanki.

Poczucie własnej wartości zaczynają dzieci tworzyć w wieku przedszkolnym. Swoje zdolności i możliwości często oceniają bardzo wysoko, nie doceniając stopnia trudności zadań. Kończąc edukację przedszkolną zaczynają formułować sądy wartościujące o sobie i innych ${ }^{3}$. W okresie wczesnoszkolnym głównym źródłem informacji o sobie samym w coraz większym stopniu staje się własna refleksja nad sobą i swoimi działaniami, przez co samoocena staje się coraz bardziej realistyczna i niezależna od zmiennych opinii otoczenia.

Według ojca współczesnej psychologii Williama Jamesa poczucie własnej wartości jest stanem uczuć takich jak zawstydzenie, zadowolenie, czy satysfakcja, powstające w odpowiedzi na doświadczane sukcesy w stosunku do oczekiwań względem siebie ${ }^{4}$. Jest konsekwencją całego zbioru sukcesów i porażek w relacjach ze światem. Wysoka samoocena napędza kolejne sukcesy dziecka, zaś niska, będąca konsekwencją problemów domu i w szkole, przyczynia się do kolejnych trudności i niepowodzeń5.

Samoocena jest ewaluacją własnej osoby. Może dotyczyć poszczególnych aspektów własnej osoby lub tworzyć ocenę ogólną, globalną

\footnotetext{
1 P. K. Oleś, Wprowadzenie do psychologii osobowości, Warszawa 2003, s. 237.

2 P. K. Oleś, Wprowadzenie do psychologii..., op. cit., s. 235.

3 G. Rudkowska, Samooceny a oceny rówieśników dzieci $w$ wieku przedszkolnym i wczesnoszkolnym, „Psychologia Rozwojowa” 2005, t. 10, nr 2, s. 61-71.

${ }^{4}$ M. E. P. Seligman, W małym ciele duży zuch, Gliwice 2010, s. 43.

5 Ibidem, s. 47.
} 
i jest jednym z najważniejszych rezultatów rozwojowych $\mathrm{w}$ wieku szkolnym. Częste sukcesy oraz pozytywne informacje zwrotne od rodziców, nauczycieli, trenerów i rówieśników przyczyniają się do uformowania wysokiej, realistycznej samooceny, stanowiącej cenny kapitał na przyszłość, który zwiększa odporność na niepowodzenia i efektywność $w$ radzeniu sobie $z$ trudnościami. Kiedy zostanie ukształtowana zachowuje względną trwałość i znacznie trudniej ją przeformułować. Niemniej, na przestrzeni życia w zakresie samooceny zachodzą zmiany: obniżenie $\mathrm{w}$ okresie dorastania, stopniowy wzrost w trakcie dorosłości i znów obniżenie u schyłku życia6.

Realistyczna opinia o sobie adekwatnie określa możliwości i daje wgląd zarówno w mocne, jak i słabe strony dziecka, jest więc pomocna w wyznaczaniu celów, osiąganiu sukcesów i zmniejszaniu ryzyka porażek. Przecenianie lub niedocenianie swoich możliwości utrudnia dopasowanie zadań i zmniejsza szanse na kolejne sukcesy. Głównymi mechanizmami kształtującymi nierealistyczną samoocenę jest brak właściwych informacji zwrotnych, koncentracja na słabych stronach dziecka, negowanie lub niedopuszczanie do jakiejkolwiek krytyki oraz nieadekwatny system kar i nagród7.

Szczególne znaczenie dla dzieci w wieku szkolnym mają nauczyciele. Spójne i konsekwentne oddziaływania obojga rodziców i nauczycieli umożliwiają budowanie, rozwijanie i utrwalanie właściwego obrazu świata dziecka. Poprzez posiadaną wiedzę i umiejętności nauczyciel jest traktowany jako źródło kompetencji, których opanowanie przybliża dziecko do świata dorosłych. Jego pochwała, nagana czy ignorancja kształtuje samoocenę i poczucie własnej skuteczności dziecka. Doznawanie radości ze swoich osiągnięć wraz z przychylną oceną społeczną, staje się źródłem wysokiej i realistycznej samooceny. Sukces osiągany na drodze świadomych i ponawianych wysiłków uczy wytrwałości, odporności na niepowodzenia i przeszkody w działaniu

\footnotetext{
${ }^{6}$ P. K. Oleś, Wprowadzenie do psychologii..., op. cit., s. 262.

${ }^{7}$ K. Appelt, Wiek szkolny. Jak rozpoznać potencjał dziecka?, [w:] Psychologiczne portrety człowieka, A. I. Brzezińska (red.), GWP, Gdańsk 2005, s. 293-296.
} 
Aleksandra Jędrzejewska - Samoocena dziecka...

oraz radzenia sobie $\mathrm{z}$ frustracją. Jest pomocny $\mathrm{w}$ trenowaniu mechanizmów samokontroli, rozwijaniu poczucia odpowiedzialności, pozwala tworzyć optymistyczny obraz rzeczywistości, jako otoczenia dającego się zrozumieć, kontrolować i zmieniać, a siebie jako kogoś, kto może osiągać upragnione cele, bez względu na trudności ${ }^{8}$. Kumulacja sukcesów czy porażek ulega generalizacji, wywiera wpływ na przekonanie o własnej skuteczności i kształtuje oczekiwanie skuteczności osobistej w przyszłych sytuacjach?

Brak sukcesów w okresie wczesnoszkolnym i nieradzenie sobie z zadaniami, może prowadzić do poczucia nieadekwatności wobec oczekiwań społecznych oraz zahamowań w wykorzystywaniu swojego potencjału rozwojowego. Konsekwencją staje się wzrost niepowodzeń w działaniu oraz utrata pozycji w grupie rówieśniczej, będące bezpośrednią przyczyną kształtowania poczucia niższej wartości.

Według autorów zachodnich na przełomie 11 i 12 r.ż. następuje gwałtowny spadek zaufania do siebie i swoich możliwości, wyrażony silnie obniżoną oceną własnej skuteczności, oczekiwaniem porażki w działaniu oraz pesymistycznymi prognozami, co do poradzenia sobie z przyszłymi trudnościami. Za przyczynę tego zjawiska upatruje się rozpoczęcie okresu adolescencji oraz przejście na wyższy poziom edukacyjny ${ }^{10}$.

Niskie poczucie własnej wartości przejawia się w różny sposób: jako strach przed porażką, przechwałki, obawa przed życiem, usuwanie się w cień, defetyzm (brak wiary w powodzenie), wyniosłość, poczucie winy, nadużywanie szkodliwych substancji, agresywne zachowanie, kłopoty z układem trawiennym itd. ${ }^{11}$.

Ludzie posiadający negatywną samoocenę nie wykorzystują szans na osiągnięcie sukcesów, tam gdzie mają ku temu obiektywne możliwości, poza tym często generalizują konsekwencje porażki na wszel-

\footnotetext{
${ }^{8}$ R. Stefańska-Klar, Późne dzieciństwo. Młodszy wiek szkolny, [w:] Psychologia rozwoju człowieka, B. Harwas-Napierała, J. Trempała (red.), PWN, Warszawa 2010, s. 145.

${ }_{9}$ P. K. Oleś, Wprowadzenie do psychologii..., op. cit., s. 214.

10 R. Stefańska-Klar, Późne dzieciństwo..., op. cit., s.146.

11 J. Juul, Twoje kompetentne dziecko, Podkowa Leśna 2011, s. 93.
} 
kie aspekty swego funkcjonowania. Co gorsza, pragnąc dobrze wypaść w porównaniu z innymi, oczerniają ich i przypisują im negatywne atrybuty ${ }^{12}$. Swoje porażki tłumaczą wrogością zewnętrznego świata społecznego, demonstrują negatywne postawy wobec innych ludzi i zamykają się przed nimi ${ }^{13}$.

Wyraźnie negatywna nie jest niska samoocena, lecz ambiwalentna, niepewna i niespójna. Osoby o niskiej samoocenie odznaczają się większą reaktywnością na informacje zwrotne, ale również większą plastycznością, gdyż łatwo przyjmują skrajne informacje, co stanowi pewien element adaptacyjny niskiej samooceny. Niemniej, łatwiej wierzą krytyce niż pochwałom. Sukcesy wydają im się nieosiągalne, więc nie zabiegają o nie z przekonaniem i wytrwałością, raczej skupiają się na unikaniu porażek, które łatwiej przyjmują niż osoby o wysokiej samoocenie. Lepiej motywuje je lęk przed klęską niż pragnienie chwały, odwrotnie niż osoby z wysoką samooceną, które skupione są na umacnianiu siebie, a w działaniach - na swoich mocnych stronach. Osoby z niską samooceną koncentrują się na ochranianiu siebie i nastawione są na wyrównywanie swoich „braków”, unikają ryzyka, zwracania na siebie uwagi i starają się ukrywać potencjalne wady. Osoby z wysoką samooceną mając przekonanie o swoich zdolnościach eksponują swoje zalety, wykazują większą pewność siebie, chętnie przyjmują pozytywne informacje zwrotne, a negatywne ignorują ${ }^{14}$.

Przyjęło się uważać, ze nieustanne, szczodre pochwały wzmacniają samoakceptację dziecka. J. Juul (2011) uważa, że takie postępowanie rozwija u wielu osób „rozdęte ego będące marnym substytutem poczucia własnej wartości". Okazywanie dzieciom miłości przez nadmierne pochwały lub krytykę ma długotrwały wpływ na rozwój ich osobowości, bowiem kreuje się osobowości zależne, sterowane zewnętrznie. Dzieci wychowane tą metodą mają niskie poczucie własnej

\footnotetext{
12 M. Kofta, D. Doliński, Poznawcze podejście do osobowości, [w:] Psychologia. Podręcznik akademicki, J. Strelau (red.), GWP, Gdańsk 2004, T. 2. s. 581.

13 Ibidem.

${ }_{14}$ P. K. Oleś, Wprowadzenie do psychologii..., op. cit., s. 254-255.
} 
Aleksandra Jędrzejewska - Samoocena dziecka...

wartości, brakuje im zdolności realnej samooceny, a dodatkowo marnują swoją żywotność na trwające czasem całe życie, próby zdobycia sympatii innych i działania w sposób, jaki wydaje się im właściwy. Dodatkowo poprzez nieustanne dążenie do akceptacji mają tendencję do nadmiernego egocentryzmu ${ }^{15}$.

To, jak zdolni się czujemy, nie podnosi przyjemności bycia ze sobą. Na kształtowanie poczucia własnej wartości wpływają dwa doświadczenia: kiedy czujemy, że osoby najważniejsze w naszym życiu dostrzegają nas i akceptują takimi, jacy jesteśmy, a nie za to, co potrafimy zrobić. Kolejnym warunkiem jest rozumienie i akceptowanie przeżywanych uczuć i doświadczeń dziecka oraz wyrażanie odpowiednich, zgodnych jego potrzebami informacji zwrotnych. Dzieci potrzebują być dostrzeganymi, a nie osądzanymi. A nadmierne pochwały mogą być równie destrukcyjne dla poczucia własnej wartości, jak krytycyzm $^{16}$.

Ludzie mają względnie stałe skłonności do snucia określonego typu ogólnych przewidywań, rozciągniętych na skali od pesymizmu (oczekiwania tego, co najgorsze) do optymizmu (oczekiwania tego, co najlepsze). Wybór sposobu reagowania na problem wynika zarówno z sytuacji, jak i z osobowości. Nastawienie na problem np. poprzez próby usunięcia lub ominięcia źródła stresu, są bardziej prawdopodobne w przypadkach wiary wpływu na sytuację. Reakcje skierowane ku własnym emocjom, są bardziej prawdopodobne, gdy ludzie nie sądzą, aby ich działania mogły coś zmienić. Optymiści mają większą skłonność do reakcji nastawionych na problem, a pesymiści - skierowanych do wewnątrz. Optymiści przedkładają aktywne rozwiązywanie problemów poprzez konkretne, zaplanowane kroki zmierzające do rozwiązania trudności, są bardziej skoncentrowani na swoich działaniach i elastyczni, co sprzyja skutecznej adaptacji. Dzięki optymizmowi pokonuje się wiele trudności i obaw, które pesymistom wydają się nie do przebycia. Optymiści również starają się dostrzec jasne

\footnotetext{
15 J. Juul, Twoje kompetentne dziecko, op. cit., s. 103.

16 Ibidem, s. 89-100.
} 
strony złych sytuacji. Pesymiści natomiast częściej zaprzeczają problemom, uciekają od nich i poddają się im, co nie sprzyja zdrowiu psychicznemu i fizycznemu ${ }^{17}$.

Z poczuciem własnej wartości związany jest pewien stan umysłu, nazywany stylem wyjaśniania. Postrzeganie samego siebie w złym świetle nie jest bezpośrednią przyczyną porażki, lecz przekonanie, że problemy będą trwały wiecznie i uniemożliwią osiągnięcie czegokolwiek. To powoduje, że przestaje się podejmować jakiekolwiek starania, poddaje się losowi, kierując się ku kolejnym porażkom, obniżającym samoocenę ${ }^{18}$.

Większość dzieci w wieku poniżej ośmiu lat ma już swój styl wyjaśniania. Dzieci, szczególnie dziewczęta, przed okresem pokwitania są wielkimi optymistami, pełnymi nadziei i uodpornionymi na bezradność. Większość uważa, że pomyślne wydarzenia będą trwały zawsze, będą dla nich korzystne we wszystkich sytuacjach i są ich zasługą. Wydarzenia niepomyślne zdarzają się od czasu do czasu, niejako na uboczu życia, szybko przemijają i zawsze wynikają z winy innej osoby. Wydaje się, że żadna osoba dorosła nie ma takich pokładów nadziei na pozytywną przyszłość, jak dziecko. W okresie pokwitania dzieci tracą znaczną część optymizmu i odporności na niepowodzenia. Te, które uzyskują wyniki powyżej przeciętnej na skali optymizmu, w przyszłości rzadziej będą ulegać depresji, osiągną więcej i będą zdrowsze, niż dzieci uzyskujące wyniki zdecydowanie niższe ${ }^{19}$.

Na podstawie badań okazuje się, że styl wyjaśniania sukcesów i porażek przez dzieci, kształtowany jest przez trzy źródła. Pierwszym są wyjaśnienia osoby wychowującej dziecko, zazwyczaj matki, która określa przyczyny zdarzeń, mających miejsce w codziennych sytuacjach w dzieciństwie. Drugim źródłem jest forma uwag krytycznych, których dziecko wysłuchuje, od różnych osób, w domu i w szkole, kiedy mu się nie powiedzie. Jeżeli przyczyny niepowodzeń określane

\footnotetext{
17 L. A. Pervin, Psychologia osobowości, Gdańsk 2002. s. 330-334.

18 M. E. P. Seligman, $W$ małym ciele..., op. cit., s. 48.

19 Ibidem, s. 191-193.
} 
Aleksandra Jędrzejewska - Samoocena dziecka...

są jako stałe i o zasięgu uniwersalnym, obraz własnej osoby staje się pesymistyczny. Trzecim źródłem są kryzysy, które mają miejsce w dzieciństwie. Pokonane trudności kształtują optymizm i postrzeganie niepowodzeń jako chwilowe i zmienne. Jeśli pozostają stałe i o zasiągu uniwersalnym, są początkiem rodzącej się bezradności ${ }^{20}$.

Dziecko uczy się pesymizmu od dorosłych, których darzy szacunkiem i z którymi spędza większość czasu. Jest jak gąbka, która wchłania wszystko, „co się mówi wraz z tym jak się mówi”21. Wsłuchuje się w interpretacje niepowodzeń dorosłych i naśladuje ich tłumaczenia. Głośna samokrytyka dorosłego w obecności dziecka kształtuje jego samoobwiniający sposób wyjaśniania zdarzeń. Nadmierne samooskarżanie się wywołuje wysokie poczucie winy i wstydu, co zniechęca do podejmowania prób zmiany. Ciągłe obwinianie się za wszelkie przydarzające się niepowodzenia zwiększa ryzyko depresji zarówno u dzieci jak i dorosłych. Z kolei brak jakiegokolwiek krytyki osłabia poczucie odpowiedzialności i utwierdza je przekonaniu, że niczego nie trzeba zmieniać.

Ważne jest by nauczyć się odpowiedniego podejścia do samego siebie, wziąć odpowiedzialność za własne czyny i naprawiać swoje niewłaściwe zachowanie, lecz z drugiej strony nie chcemy by dzieci traciły poczucie własnej wartości w sytuacjach, gdy nie są niczemu winne ${ }^{22}$.

Niepochlebne komunikaty o trwałym i globalnym charakterze zaszczepiają $\mathrm{w}$ dziecku pesymistyczny styl wyjaśniania. Negatywna ocena charakteru lub zdolności dziecka przyczynia się do kształtowania poczucia bezradności wobec niemożliwych do zmiany cech, a tym samym efektów jego działalności. Karcone za lenistwo, utwierdzane jest w przekonaniu, że jego porażki są skutkiem trwałych i niezmiennych czynników, z którymi nie da się walczyć i zmienić. Są skazywane na niepowodzenia przy każdej następnej próbie. Gdy krytyka odnosi

\footnotetext{
${ }^{20}$ M.E.P. Seligman, Optymizmu można się nauczyć, Poznań 1993, s. 193-205.

21 Ibidem, s. 185.

22 Ibidem, s. 76.
} 
się do konkretnych i tymczasowych czynników, dziecko uczone jest optymizmu i wzmacniane jest jego poczucie kontroli nad przyszłymi zdarzeniami ${ }^{23}$.

Jako przykłady pozytywnych i negatywnych komunikatów mogą służyć wypowiedzi²4:

\begin{tabular}{|c|c|}
\hline KRYTYKA (OCENA) NEGATYWNA & KRYTYKA (OCENA) POZYTYWNA \\
\hline $\begin{array}{l}\text { Trwałe (pesymistyczne) podejście: } \\
\text { Nie posprzątałeś zabawek. Dlaczego } \\
\text { nigdy nie robisz tego, o co cię proszę? }\end{array}$ & $\begin{array}{l}\text { Tymczasowe (optymistyczne) } \\
\text { podejście: } \\
\text { Nie posprzątałeś zabawek. Dlaczego nie } \\
\text { zrobiłeś tego, o co cię prosiłam? }\end{array}$ \\
\hline $\begin{array}{c}\text { Globalne podejście: } \\
\text { Ona jest nieśmiała. Nigdy nie bawi się z } \\
\text { innymi dziećmi. }\end{array}$ & $\begin{array}{l}\text { Lokalne podejście: } \\
\text { Ona ma kłopot } z \text { dołączeniem się do } \\
\text { grupy bawiących się dzieci. }\end{array}$ \\
\hline $\begin{array}{l}\text { Podejście wewnętrzne, ogólne, } \\
\text { pasywne: } \\
\text { Kolejna dwójka? Nie należysz do } \\
\text { prymusów. }\end{array}$ & $\begin{array}{c}\text { Podejście wewnętrzne, konkretne, } \\
\text { aktywne: } \\
\text { Kolejna dwójka? Musisz więcej czasu } \\
\text { poświęcić na naukę. }\end{array}$ \\
\hline
\end{tabular}

Oprócz rodziców, bardzo istotny jest wpływ nauczycieli i trenerów, ponieważ ich codzienną pracą jest ocenianie sukcesów i porażek dziecka. Nieumiejętna krytyka mentorów kształtuje w dziecku negatywną teorię siebie i świata. Ten sam nauczyciel potrafi ograniczyć się tylko do stwierdzenia faktów, jak również poprzez krytykę odzwierciedlić swoje uprzedzenia lub niewłaściwe nawyki komentowania. Szczególnie często zauważa się różnice w sposobie oceniania dziewcząt i chłopców. Wyjaśnieniem przyczyn kłopotów w nauce u dziewcząt są zazwyczaj braki w umiejętnościach („matematyka nie jest twoją mocną stroną"), co daje informację o trwałym, niezmiennym charakterze niepowodzeń. Te stwierdzenia odwzorowują się w późniejszych wyjaśnieniach dziecka np.: „nie rozumiem matematyki”, „mam to po mamie”. W przypadku występowania problemów z nauką

\footnotetext{
23 Ibidem, s. 81.

24 Ibidem, s. 81-82.
} 
Aleksandra Jędrzejewska - Samoocena dziecka...

u chłopców, często obwiniane są czynniki tymczasowe i zmienne np. słabe staranie się, nieuwaga, rozrabianie ("gdybyś się lepiej postarał, to praca byłaby lepsza”, „nie uważałeś, gdy tłumaczyłam”)25.

Rozwiązaniem wcale nie jest pozbawianie dzieci problemów. Często rodzice myślą, że szczęśliwe dzieci to dzieci bez trosk i kłopotów. Interweniując $\mathrm{w}$ każdej niekomfortowej dla dziecka sytuacji pozbawiają go opanowania niezbędnych umiejętności społecznych i wysyłają komunikat: „nie jesteś sam sobie poradzić”. Takie dzieci szybko zaczynają oczekiwać, że rodzice, a potem również inni ludzie rozwiążą wszelkie ich problemy. W ten sposób dziecko pozbawiane jest odpowiedzialności za dokonywane wybory, jak również pogłębia się jego bezradność i obniża poczucie wartości. W sytuacji problemowej będzie lepiej, gdy dorosły okaże wsparcie i pomoc w dojściu do samodzielnego rozwiązania przez dziecko ${ }^{26}$.

Optymizm nie polega na obwinianiu innych za własne niepowodzenia. Uchylanie się od odpowiedzialności jedynie pogarsza sytuację. Nie chodzi o unikanie smutku i złości czy zaprzeczanie tychże uczuć, bowiem one skłaniają nas do chęci zrozumienia problemu i zmiany jego przyczyn. Optymizm wzbudza w dziecku ciekawość świata, uczy stawiać czoła przeciwnościom i skutecznie zwalczać problemy. Dlatego należy uczyć dzieci trafnego oceniania faktów. Kwestionując przekonania dziecka ważne jest, by pokrywały się z rzeczywistością. Zaprzeczanie jednej nieprawdy inną, nie przynosi rezultatów. Gdy dziecko mówi: „Nie nadaję się do drużyny, jestem fajtłapą”, proste zaprzeczenie "to nieprawda", nie jest rozwiązaniem. Potrzebne jest zwrócenie uwagi na konkretny problem i przypomnienie choć drobnego sukcesu związanego daną sytuacją, który kwestionowałby myślenie dziecka i dawał nadzieję na zmianę: „Może rzeczywiście miałeś gorszy dzień. Popracuj nad celnością strzału. Czy pamiętasz, jak świetna była twoja obrona podczas ostatniego meczu?"27.

\footnotetext{
${ }^{25}$ M. E. P. Seligman, $W$ małym ciele..., op. cit., s. 125.

26 Ibidem, s. 262.

27 Ibidem, s. 327-328.
} 
Brak zależności (wpływu na sytuację) i poczucia kontroli wywołuje chęć poddania się, pasywność i depresję, co potwierdziły setki eksperymentów na zwierzętach i ludziach. Dziecko staje się bezradne, gdy nie obserwuje zależności pomiędzy swoim działaniem a pojawiającymi się efektami. Zaś poczucie kontroli wzmacnia samopoczucie i aktywność. To nie dźwięk grzechotki wywołuje śmiech dziecka, lecz fakt, że to ono go wywołało 28 .

Popularnym narzędziem psychologicznym do badania samooceny jest Skala Samooceny Rosenberga, gdzie oceniana jest względnie stała i świadoma postawa wobec Ja. Zadaniem badanego jest udzielenie odpowiedzi na 10 pytań, dokonując wyboru na czterostopniowej skali, w jakim stopniu zgadza się z każdym z określonych stwierdzeń. Pytania dotyczą ogólnego poziomu samopoczucia, zadowolenia z siebie i swoich działań. Innym przykładem kwestionariusza samooceny jest Kwestionariusz Samoopisu wg M. Dymkowskiego, który również bazuje na świadomej ocenie Ja.

W literaturze spotkać można postulaty dotyczące przejawów samooceny nie tylko $\mathrm{w}$ sferze świadomości jednostki, ale również w obrębie procesów nieświadomych. Według Greenwalda pomiar samooceny oparty na samoopisie jest obciążony wpływem zmiennych pośredniczących: aprobaty społecznej, tendencji do robienia dobrego wrażenia, obawy przed oceną, samooszukiwania i samowzmacniania. Pomiar samooceny na poziomie jawnym może być nietrafny i dostarczać motywacji osobie badanej do prezentowania się w pozytywnym świetle lub skłonności do stosowania mechanizmów obronnych. Na globalną samoocenę jednostki według modelu dwuskładnikowego, składają się oba poziomy samooceny: jawny - dostępny świadomości i komunikowany wprost otoczeniu oraz utajony - poziom niedostępny jednostce na poziomie świadomym, którego weryfikacja jest mocno utrudniona ${ }^{29}$.

\footnotetext{
28 Ibidem, s. 305-306.

${ }^{29}$ M. I. Porębiak, Samoocena jawna i utajona: model dwuskładnikowy, „Nowiny Psychologiczne" 2005, nr 2.
} 
Aleksandra Jędrzejewska - Samoocena dziecka...

Przeprowadzanie testów wśród dzieci jest obarczone większymi błędami niż w przypadku osób dorosłych. Dzieci starają się wypaść lepiej niż rzeczywiście o sobie myślą. Ukrywają swoje objawy i negatywne opinie, szczególnie przed rodzicami. Innym błędem może być nierzetelnie wykonanie testu, z powodu chociażby niechęci wobec niego. Zmienny i tymczasowy nastój dziecka może również znacząco wpłynąć na wynik ${ }^{30}$.

W obliczu zdarzeń wartościowanych przez podmiot, jako sukces lub porażka poziom samooceny wykazuje istotną tendencję do zmian, szczególnie u osób o niskim jej poziomie, zarówno na poziomie świadomym jak i nieświadomym, lecz samoocena utajona wykazuje większą stabilność ${ }^{31}$. W okresie rozwojowym, kiedy poczucie wartości dziecka kształtuje się, jest ono szczególnie wrażliwe na fluktuacje pod wpływem przeżywanych doświadczeń.

W celu dokonania samooceny dziecka poprzez pytania "nie wprost” można posłużyć się Kwestionariuszem Atrybucyjnego Stylu u Dzieci CASQ M. Seligmana32. Wyniki uzyskane tym narzędziem wydają się bardziej miarodajne i ukazujące bliższy rzeczywistości obraz poczucia wartości dziecka. Kwestionariusz oparty jest na stylu wyjaśniania niepomyślnych i pomyślnych wydarzeń, które zdarzyły się lub mogłyby się wydarzyć. Odwołuje się do sposobu myślenia, który wywodzi się wprost z opinii, jaką mamy o sobie samym i o swoim miejscu na świecie, i zależy bezpośrednio od tego, czy uważamy się za osobę wartościową. W kwestionariuszu oceniane są trzy istotne wymiary stylu wyjaśniana: stałość, zasięg i personalizacja, które decydują o tym, czy jesteśmy optymistami czy pesymistami ${ }^{33}$.

W celu porównania dwóch różnych sposobów spojrzenia na poziom samooceny, przeprowadzono badanie chłopca w wieku 11 lat, u którego z powodu problemów występujących w szkole pojawiły się

\footnotetext{
30 M. E. P. Seligman, $W$ małym ciele..., op. cit., s. 105.

31 M. I. Porębiak, Samoocena jawna..., op., cit.

32 M. E. P. Seligman, Optymizmu można..., op. cit., s. 180-189.

33 Ibidem, s. 71-72.
} 
problemy emocjonalne (obniżony nastrój, niechęć do szkoły, niepokój, smutek, drażliwość), potwierdzone badaniem psychologicznym. Badanie samooceny przeprowadzono po ośmiu miesiącach wprowadzenia korzystnych zmian życiu szkolnym dziecka. Było to przejście do klasy czwartej, z czym wiązała się zamiana jednego nauczyciela na kilku innych oraz określenie problemu dziecka, jakim było stwierdzenie dysleksji i wprowadzenie środków pomocy (dostosowanie wymagań edukacyjnych do możliwości psychofizycznych dziecka, zajęcia korekcyjno-kompensacyjne).

Badanie chłopca za pomocą Kwestionariusza M. Dymkowskiego (Karta Samoopisu ${ }^{34}$ ) wykonano w dwóch formach: jakim się czuje oraz jakim chciałby być (Ja idealne). W zakresie wszystkich wymienionych cech badany określa siebie istotnie lepiej niż rówieśników. W siedmiu cechach chłopiec ocenia się na maksymalnie wysokim poziomie, natomiast do osiągnięcia ideału w pozostałych siedmiu brakuje mu najwyżej $20 \%$. Wyniki te przedstawiają zdecydowany, powyżej przeciętnej poziom zadowolenia z siebie.

Drugim kwestionariuszem wykorzystanym w badaniu był opisany powyżej Kwestionariusz Seligmana, odpowiednio przygotowany dla dzieci w wieku 8-13 lat, w którym ocena wyników następuje według poniższych poziomów:

1 - Wielki optymizm, myślenie optymistyczne

2 - Umiarkowany optymizm

3 - Przeciętny pesymizm, wynik przeciętny

4 - Umiarkowany pesymizm

5 - Wielki pesymizm

\footnotetext{
${ }^{34}$ Kwestionariusz udostępniony został przez Instytut Psychologii Uniwersytetu Wrocławskiego.
} 
Aleksandra Jędrzejewska - Samoocena dziecka...

Badanie chłopca ujawniło następujące wyniki:

\begin{tabular}{|c|c|}
\hline WYDARZENIA NIEPOMYŚLNE & WYDARZENIA POMYŚLNE \\
\hline $\begin{array}{c}\text { stały charakter niepowodzeń: } \\
\text { PRZECIĘTNY PESYMIZM }\end{array}$ & $\begin{array}{c}\text { stały charakter pomyślnych wydarzeń: } \\
\text { PRZECIĘTNY PESYMIZM }\end{array}$ \\
\hline zasięg niepowodzeń: & $\begin{array}{c}\text { zasięg pomyślnych wydarzeń: } \\
\text { WIELKI OPTYMIZM }\end{array}$ \\
\hline \multicolumn{2}{|c|}{ poziom nadziei: } \\
\hline PATRZENIE W PRZYSZłOŚC Z PEWNĄ NADZIEJĄ (wynik przeciętny) \\
\hline $\begin{array}{c}\text { personalizacja niepowodzeń: } \\
\text { PRZECIĘTNA SAMOOCENA }\end{array}$ & $\begin{array}{c}\text { personalizacja powodzenia: } \\
\text { GLĘBOKI PESYMIZM }\end{array}$ \\
\hline $\begin{array}{c}\text { Ogółem wydarzenia niepomyślne: } \\
\text { UMIARKOWANY OPTYMIZM }\end{array}$ & $\begin{array}{c}\text { Ogółem wydarzenia pomyślne: } \\
\text { PRZECIĘTNY PESYMIZM }\end{array}$ \\
\hline \multicolumn{2}{|c|}{ ogólny poziom optymizmu: UMIARKOWANY OPTYMIZM } \\
\hline
\end{tabular}

Z powyższego testu wynika, że ogólne myślenie chłopca jest umiarkowanie optymistyczne, o poziom wyżej niż wartość przeciętna. Według chłopca, wydarzenia pomyślne mają zarówno stały charakter (z natury jestem wesoły), jak i chwilowy (czasami ludzie sa mili). Przyczyny wydarzeń pomyślnych mają zazwyczaj zasięg uniwersalny (mam szczęście), co świadczy o dużym optymizmie chłopca w tym wymiarze. Niepowodzenia według chłopca, częściej mają charakter chwilowy (czasami jestem nieostrożny), ale mogą również mieć charakter stały (tramwaje zawsze się spóźniaja), natomiast ich zasięg bywa zarówno ograniczony (tego dnia nie uważałem) jak i uniwersalny (ta osoba jest nieuczciwa).

Na powyższe wyniki, istotnym cieniem kładzie się kolejny aspekt stylu wyjaśniania, jakim jest personalizacja, która wpływa na to, co myśli się o sobie i co wydaje się być kluczowym elementem samooceny. Pod tym względem, w zakresie wiary w swoje możliwości i powodzenie, chłopiec osiągnął najniższy poziom (głęboki pesymizm). Badany nie ufa swoim umiejętnościom i zdolnościom, i nie jest skłon- 
ny przypisywać sobie sukcesów (mam dobre stopnie, bo nauka jest tatwa).

Przeprowadzone badanie chłopca za pomocą dwóch odmiennych kwestionariuszy wskazuje na istotne różnice w wyznaczonym poziomie samooceny. Karta Samoopisu M. Dymkowskiego badająca postrzeganie cech przez dziecko, pokazuje stosunkowo wysoką samoocenę, natomiast Kwestionariusz Atrybucyjnego Stylu u Dzieci M. Seligmana ujawnia, że pomimo ogólnie optymistycznego myślenia, samoocena chłopca jest niepewna. Wydaje się, że stałość i zasięg wydarzeń są pochodną przede wszystkich stylu wyjaśniania przejętego $\mathrm{z}$ domu rodzinnego, natomiast personalizacja porażek i sukcesów kształtowana jest w znacznej mierze na arenie szkolnej, w obliczu porównań i komentarzy ze strony nauczycieli i rówieśników.

Styl wyjaśniania dziecka można rozpoznać wsłuchując się w jego tłumaczenie przyczyn zaistniałych wydarzeń. Dzieci posiadające wysoką samoocenę kompetencji szkolnych swoje sukcesy przypisują posiadanym zdolnościom, natomiast porażki uzasadniają zewnętrznym okolicznościom, takim jak niewystarczające starania czy wyjątkowa trudność. Taki rodzaj atrybucji jest motywujący do podejmowania dalszych działań. Uczniowie z poczuciem niskiej skuteczności, swoim i najczęściej stałym cechom przypisują porażki, zaś sukcesy - wystąpieniu szczęśliwych okoliczności. W ten sposób nie dostrzegają możliwości poprawy osiągnięć poprzez swoje działania, a w obliczu trudności doznają uczucia zagubienia, szybko się poddają, co prowadzi do porażki i utwierdzenia o swojej nieporadności ${ }^{35}$. Dzieci te nie łączą swoich wysiłków z osiągnięciami, przez co nie rozwijają strategii wspomagających efektywność swojej pracy intelektualnej. W konsekwencji skazuje to ucznia na regulatory zewnętrzne jako jedyny sposób motywowania do podjęcia pracy ${ }^{36}$.

35 A. Kołodziejczyk, Późne dzieciństwo - młodszy wiek szkolny, [w:] Psychologia rozwoju człowieka, J. Trempała (red.), PWN, Warszawa 2011, s. 252.

36 Ibidem. 
Aleksandra Jędrzejewska - Samoocena dziecka...

\section{Podsumowanie}

To, w jakie komunikaty dziecko się wsłuchuje od najmłodszych lat, przyczynia się do kształtowania jego wizji świata i siebie. Rodzice, nauczyciele, trenerzy określają, czy świat dziecka jest bezpieczny i czy nadarzające się sytuacje podlegają kontroli.

Już w wieku dwóch lat dzieci zaczynają werbalizować wyjaśnienia przyczynowe („mama jest niedobra”). Po ukończeniu trzeciego roku życia dostrzegają związki przyczynowo-skutkowe rządzące światem i poszukują odpowiedzi na pytania „dlaczego?”37. Usłyszane wówczas wytyczne są kierunkowskazami na resztę życia.

Szczególną rolę w kształtowaniu poczucia własnej wartości dziecka odgrywa szkoła, ze względu na okres rozwojowy, systematyczność i długotrwałość oddziaływań oraz zakres wiedzy o sobie, którą uczeń w niej zdobywa.

W społeczeństwie osiągnięć wymaga się od dzieci sprostania wysokim wymaganiom, osiągania ambitnych celów, wygrywania w rywalizacji i kolekcjonowania sukcesów. Porażka jest czymś wstydliwym i zagrażającym życiowemu dobrostanowi. Oddziaływania wychowawcze prowadzone w duchu ideologii sukcesu, mogą prowadzić do lęku przed pomyłką i perfekcjonizmu.

Każde działanie wiąże się z ryzykiem błędu, a niepowodzenia dostarczają wyraźnych informacji zwrotnych o niewłaściwie dokonanych wyborach. Wyciągając odpowiednie wnioski ustrzegamy się tych pomyłek w przyszłości. Umiejętność akceptacji niepowodzeń wymaga pokory, uznania własnej omylności oraz odwagi przyznania się do błędów. Lęk przed porażką można zmniejszyć kształtując w dzieciństwie aktywną nadzieję na sukces czyli przekonanie, że dzięki odpowiedniemu zaangażowaniu możliwe jest osiągniecie celu. Ważna jest postawa rodziców wobec osiągnięć, styl przywiązania oraz dawanie

37 M. E. P. Seligman, W małym ciele..., op. cit., s. 320-321. 
przykładu. Dorośli powinni kształtować w dzieciach przekonanie, że każdy ma prawo do błędów, bowiem są one naturalnym i nieuchronnym elementem aktywności i rozwoju. Kiedy dziecko jest kochane niezależnie od osiągnięć, czuje się bezpiecznie w obliczu niepowodzeń i łatwiej mu się z nimi zmierzyćc ${ }^{38}$.

Ważne jest, by dziecko wiedziało, że dany problem może być skutkiem wielu różnych przyczyn i umiało wziąć odpowiedzialność za swój wkład, nie obwiniając się za rzeczy, które nie są od niego zależne ${ }^{39}$. Istotne jest nauczenie dzieci trafnego diagnozowania przyczyn problemów i przekonania, że kłopoty są przejściowe i dają się pokonać poprzez odpowiednie działania. Właściwa interpretacja niepowodzenia nie spowoduje, że trudności znikną, ale ułatwi dojście do źródła problemu i skupienie się na działaniach naprawczych ${ }^{40}$. Wypracowanie w dzieciństwie odpowiedzialności za swoje sukcesy i porażki jest podstawą realnej, stabilnej i pozytywnej samooceny, decydującej o jakości życia jednostki.

\section{Bibliografia:}

Appelt K., Wiek szkolny. Jak rozpoznać potencjał dziecka?, [w:] Psychologiczne portrety człowieka, A. I. Brzezińska (red.), GWP, Gdańsk 2005.

Fortuna P., Pozytywna psychologia porażki, GWP, Sopot 2012.

Juul J., Twoje kompetentne dziecko, Wydawnictwo MiND, Podkowa Leśna 2011.

Kofta M., Doliński D., Poznawcze podejście do osobowości, [w:] Psychologia. Podręcznik akademicki, J. Strelau (red.), GWP, Gdańsk 2004

Kołodziejczyk A., Późne dzieciństwo - młodszy wiek szkolny, [w:] Psychologia rozwoju człowieka, J. Trempała (red.), PWN, Warszawa 2011.

Oleś P. K., Wprowadzenie do psychologii osobowości, seria „Wykłady z Psychologii", tom 11, Wydawnictwo Naukowe Scholar, Warszawa 2003.

Pervin L. A., Psychologia osobowości, GWP, Gdańsk 2002.

\footnotetext{
38 P. Fortuna, Pozytywna psychologia porażki, Sopot 2012, s. 133-149.

${ }^{39}$ M. E. P. Seligman, $W$ małym ciele..., op. cit.,, s. 191.

40 Ibidem, s. 255.
} 
Aleksandra Jędrzejewska - Samoocena dziecka...

Porębiak M. I., Samoocena jawna i utajona: model dwuskładnikowy, „Nowiny Psychologiczne" 2005, nr 2.

Rudkowska G., Samooceny a oceny rówieśników dzieci w wieku przedszkolnym i wczesnoszkolnym, „Psychologia Rozwojowa” 2005, t. 10, nr 2.

Schaffer H. R., Psychologia dziecka, PWN, Warszawa 2005.

Seligman M. E. P., Optymizmu można się nauczyć, Wyd. Media Rodzina, Poznań 1993.

Seligman M. E. P., W małym ciele duży zuch, Wyd. Helion, Gliwice 2010.

Stefańska-Klar R., Późne dzieciństwo. Młodszy wiek szkolny, [w:] Psychologia rozwoju człowieka, B. Harwas-Napierała, J. Trempała (red.), PWN, Warszawa 2010. 